\title{
Screening Possible Drug Molecules for Covid-19. The Example of Vanadium (III/IV/V) Complex Molecules with Computational Chemistry and Molecular Docking.
}

\section{Manos C. Vlasiou ( $\sim$ vlasiou.m@unic.ac.cy)}

University of Nicosia https://orcid.org/0000-0002-8356-0868

Kyriaki S. Pafiti

University of Nicosia

\section{Research Article}

Keywords: Docking, Vanadium, Covid-19, Drug

Posted Date: June 10th, 2020

DOI: https://doi.org/10.21203/rs.3.rs-34033/v1

License: (c) (1) This work is licensed under a Creative Commons Attribution 4.0 International License. Read Full License

Version of Record: A version of this preprint was published at Computational Toxicology on May 1st, 2021. See the published version at https://doi.org/10.1016/j.comtox.2021.100157. 


\section{Abstract}

After the Covid-19 pandemic and the aggressively infection control measures taken by the governments in the whole world, the need for a rapid pharmaceutical solution was more that necessary. The computer aided chemistry and molecular docking is a rapid tool to drug screening and investigation. Moreover, more metal based drugs are tested daily by research institutes for their antiviral activity. Here, we used theoretical studies on previously published biological active complex molecules of vanadium as an example of evaluating possible drug candidates before entering the laboratory. Our findings suggest that theoretical investigation should always precede on drug discovery.

\section{Introduction}

Nowadays the scientific community faces a unique situation due to the Covid-19 disease. The World Health Organization (WHO), declared the coronavirus disease a global pandemic in March 2020 [1]. Generally speaking, Covid-19 is a member of Betacoronoviruses, the former human coronaviruses SARS and MERS [2].

SARS-CoV- 2 belongs to the +RNA virus family that utilize single-stranded positive-sense RNA molecules as genomes. SARS-CoV-2, a positive strand RNA virus encodes four structural proteins the matrix (M), small envelope (E), spike (S) and nucleocapsid phosphoprotein (N). Moreover, sixteen non-structural proteins (nsp1-16), the nucleocapsid phosphoprotein $N$ which is essential for linking the viral genome to the viral membrane and its N-terminal RNA binding domain (N-NTD) that captures the RNA genome [3].

The effective options of drug therapy and vaccination are currently under evaluation and our societies are trying to supress the disease with aggressively infection control measures [4]. Having in mind these facts we are underlying the need of a rapid evaluation of possible drug candidates. This will save money and time to the drug industry in order to shift the research in a clearer synthetic path. As far as now, very few studies, discussed bioinformatics [5] and computer aided techniques as a more efficient way to fight the Covid-19 pandemic disease. In addition, Shi et al. [6] developed a molecular docking web-based server to discover new drug targets, or active compounds. Yan et al. [7] conclude that a structure-based rational design of binders with enhanced affinities the $S$ protein of the coronaviruses may facilitate development of decoy ligands or neutralizing antibodies for suppression of viral infection, and Lung et al. [8] suggested a potential SARS-CoV-2 RdRp inhibitor for further study using molecular docking studies. Molecular docking has several strengths, among which the method's ability to screen large compound databases at low cost compared to experimental techniques $[9,10]$ and Open source software development provides many advantages to users of modelling applications, not the least of which is that the software is free and completely extendable $[11,12]$.

On the other hand, there is an increase interest in the development of metal-based drugs $[13,14]$ and some of them exhibited interest activities against viruses $[15,16]$. Vanadium complexes are in use because of the low toxicity of vanadium metal in comparison with others such as platinum. Pharmaceuticals based 
on vanadium complexes have attracted the interest of scientists due to the biological activity of vanadium molecules, for example antidiabetic properties, and their low toxicity [17].

Herein, we describe the use of five vanadium (III/IV/V) complexes as potential candidates in drug screening with computer aided chemistry for Covid-19. In particular, we used the example of $\beta$-tocDEA $\left(\mathrm{V}^{5+}\right)$ and $\beta$ tocDPA $\left(\mathrm{V}^{4+}\right)$ as reported in [17], the binuclear $\mathrm{V}^{5+}$ bdeah [18], and binuclear $\mathrm{V}^{3+}$ bicah complex molecule [19].Finally based on the theoretical studies we designed for the first time the $\mathrm{V}^{5+} \mathrm{Xn}$ complex molecule, a vanadium complex with xanthohumol which is a prenylated chalcone. We performed molecular dynamics studies, DFT studies and molecular docking studies against BSA (transport protein), 6M03 (Covid-19 main protease), 6M71 (SARS-COV-2 RNA-dependent polymerase) and 6YI3 the Nterminal RNA-binding domain of the SARS-CoV-2 nucleocapsid phosphoprotein.

\section{Materials And Methods \\ 2.1 Materials}

To create 2D and 3D structures of the ligand molecules, Chem3d Pro 12.0 and AVOGADRO 1.90.0 software programmes were used. Ligand optimisations were done by ORCA 4.1.1 software while ligands and receptor preparation studies were done by Chimera 1.14. Molecular docking studies were carried out by Autodock 4.2 and docking results were analysed by Chimera 1.14 program. Additionally, calculations on docking studies performed using iGEMDOCK 2.1 software. BSA, 6M03, 6M71 and 6YI3 coded crystal structures were selected from Protein Data Bank (www.rcsb.org). Ligand molecules were collected by literature [17-19].

\subsection{Methods}

\subsubsection{Computational Chemistry}

Geometric optimization calculations were performed in accordance with DFT method [20]. Frequency calculations were performed to obtain thermodynamic properties and to verify that each optimization achieved an energy minimum. The quantum chemical descriptors extracted directly from the ORCA output file were Huckel charge, electronic density, dipole moment, the energy of the highest occupied molecular orbital (HOMO), and the energy of the lowest unoccupied molecular orbital (LUMO) $[21,22]$.

\subsubsection{Receptor Preparation}

All water molecules were removed, hydrogen atoms were added, the end residues were repaired, and energy minimization was performed on the protein. Docking calculations were performed through 
Autodock generation using the ligand, the protein was fixed while the ligand was flexible, and the default parameters were used as described [23].

\subsubsection{Docking Studies}

Docking studies were performed with a number of 150 individuals in population, maximum energy evaluations of $2,500,000$, and maximum generation of 54,000 to result in 100 docking poses [24].

\section{Results And Discussion}

\subsection{Theoretical Chemistry}

The optimized structures of the studied complex molecules are depicted in Fig.1a. The DFT results are within the same range as MP2. For Vbicah and Vbdea we can say that the theoretical studies agreed with the experimentally $x$-ray structures from the literature. The structures of xanthohumol molecule and complexed with vanadium structure of the molecule can be found in Fig.1b. The Huckel charges and the calculated molecular geometry parameters can be found in Tables A1, A2 and B respectively in the supplementary material. Calculated geometry parameters for Vbicah and Vbdeah are in conformity with experimental ones $[18,19]$. It is widely known that DFT calculation results strongly depend on used functionals and to some extend on used solvents in model [25]. The molecular electrostatic potential and the solvent accessibility of all the molecules studied in this paper are shown in Fig.2a and Fig.2b. These were in good correlation with Huckel charges values.

As can be seen from Table 1. the calculated total energies of Vtocdea, Vtocdpa and VXn are in order from lowest to highest Vtocdea

The value of the energy difference between HOMO and LUMO as well as the highest occupied molecular orbital (EHOMO) and lowest unoccupied molecular orbital (ELUMO) energies plays a very important role in stability and reactivity of molecules. The EHOMO energies of molecules show the molecule's ability to give electrons. On the other hand, ELUMO characterizes the ability of the compound to accept electrons. The energy gap of Vtocdea and Vtocdpa is similar, a fact that it is corelated with the experimental values [17], showing that the vanadium ion in Vtocdea is in oxidation state +5 while in Vtocdpa the vanadium ion is in oxidation state +4 . The electronic correlation effects play an essential role in the stability of these type of systems, and therefore, it will affect the equilibrium distances and the interaction energies.

Electronegativity $(X)$ is a measure of the power of an atom to attract a bonding pair of electrons. According to this theorem is expressed as follows. Based on equation (1) larger $\Delta$ gap always indicates lower chemical reactivity and higher kinetic stability of the investigated species. The chemical reactivity of molecules is caused by the simultaneous effect of different parameters. 


$$
\chi=\frac{-\left(E_{\mathrm{HOMO}}+E_{\mathrm{LUMO}}\right)}{2}
$$

The distribution and energy of $\mathrm{HOMO}$ is an important parameter to explain the antioxidant potential of phenolic antioxidants. The electron-donating capacity of the molecule can be predicted by looking at the energy values of HOMO. The value of the energy difference between HOMO and LUMO as well as the highest occupied molecular orbital (EHOMO) and lowest unoccupied molecular orbital (ELUMO) energies plays a very important role in stability and reactivity [24].

Table 1. Calculated minimised energies for complex molecules of Vanadium with natural phenolic ligands

\begin{tabular}{cccc}
\hline Calculated Values & Vtocdea & Vtocdpa & VXn \\
\hline Stretch & 32.54 & 81.37 & 45.28 \\
Bend & 84.91 & 215.51 & 182.24 \\
\hline Stretch-Bend & 1.27 & -14.20 & 0.26 \\
\hline Torsion & 18.15 & 22.38 & -1.47 \\
\hline Non-1.4 VDW & -19.89 & -23.76 & -0.87 \\
\hline $1.4 \mathrm{VDW}$ & 36.08 & 37.86 & 20.33 \\
\hline Dipole-Dipole & 2.15 & ------ & 0.65 \\
\hline Total Energy & $156.2 \mathrm{Kcal} / \mathrm{mol}$ & $354.79 \mathrm{Kcal} / \mathrm{mol}$ & $246.43 \mathrm{Kcal} / \mathrm{mol}$ \\
\hline
\end{tabular}

As we can see in Table 2. Vtocdea and Vtocdpa have similar reactivities and kinetic stability. The same is expected for VXn which is a complex molecule designed based on these two. Based on these results we have used the geometry of the model Tocopherol to design VXanthohumol (both are vanadium complexes with natural ligands) and the results confirmed that.

Table 2. Quantum chemical parameters for studied molecules

\begin{tabular}{ccccc}
\hline Complex Molecule & Metal Ion & HOMO & LUMO & $\Delta$ gap \\
\hline Vbicah & $\mathrm{V}(10) \mathrm{V}^{3+}$ & -13.043 & 0.526 & 13.569 \\
Vbicah & $\mathrm{V}(23) \mathrm{V}^{3+}$ & -15.036 & 36.811 & 51.847 \\
\hline Vbdea & $\mathrm{V}(16) \mathrm{V}^{5+}$ & -14.557 & 32.555 & 47.112 \\
\hline Vbdea & $\mathrm{V}(21) \mathrm{V}^{5+}$ & -15.298 & 36.063 & 51.361 \\
\hline Vtocdea & $\mathrm{V}^{5+}$ & -20.056 & 41.397 & 61.453 \\
\hline Vtocdpa & $\mathrm{V}^{4+}$ & -20.292 & 41.825 & 62.117 \\
\hline VXn & $\mathrm{V}^{4+}$ & -18.801 & 43.473 & 62.274 \\
\hline
\end{tabular}

\subsection{Molecular Docking}

Molecular docking method is one of the frequently referred structure-based design methods $[28,29]$. We decided that because the ligand molecules would be screened as a drug candidate for Covid-19, to perform studies with several related proteins to Covid-19 as we discussed in introduction, and at least 
with one plasma transport protein. In Fig 4. We can see the crystal structures that we used for molecular docking studies.

The Vtocdea molecule interaction with $6 \mathrm{YI} 3$ is depicted in Fig 5. while, if Fig 6 . we can se the relatively position of Vtocdea and VXn molecules on $6 \mathrm{M} 03$ and $6 \mathrm{M} 71$ respectively. Moreover, the hydrogen bonding interactions of amino acid residue of structure 6M71 with Vtocdpa molecule, are shown in Fig 7.

Docking analyses showed that VXn coded ligand has the best binding score among all ligands with BSA protein, followed by $\mathrm{Xn}$ with a binding free energy of $-108.72 \mathrm{kcal} / \mathrm{mol}$. It makes hydrogen bonds with ASP108, PR0146, TYR147 and ILE455 (four H bonds), and also interacts with BSA with Van der Waals forces with a binding free energy of $-93.23 \mathrm{kcal} / \mathrm{mol}$. Regarding the N-terminal RNA-binding domain of the SARS-CoV-2 nucleocapsid phosphoprotein (6YI3) the molecule Vbicah has a binding free energy of $-108.88 \mathrm{kcal} / \mathrm{mol}$, followed by VXn with $-105.23 \mathrm{kcal} / \mathrm{mol}$. In fig. 8 we are seeing the percentage interaction energies of the amino acid's residue of $6 \mathrm{YI} 3$ on the studied molecules. In particular, the highest energy interaction of $\mathrm{Xn}$ molecule with $6 \mathrm{YI} 3$ is related with the amino acid glutamine, while for $\mathrm{VXn}$ the highest energy related interaction with the same protein comes from the amino acid arginine. Interestingly both Vbdeah and Vbicah interact more with the amino acid asparagine of the $6 \mathrm{YI} 3$.

Continuing with SARS-COV-2 RNA-dependent polymerase (6M71) starting with the ligand molecule with the highest affinity to the protein, Vbicah is the first with $-102.66 \mathrm{kcal} / \mathrm{mol}$ followed by Vtocdea -98.91 $\mathrm{Kcal} / \mathrm{mol}$, Vtocdpa $-97.06 \mathrm{Kcal} / \mathrm{mol}, \mathrm{Xn}-96.03 \mathrm{Kcal} / \mathrm{mol}, \mathrm{VXn}-93.64 \mathrm{Kcal} / \mathrm{mol}$ and finally Vbdea with $-86.47 \mathrm{Kcal} / \mathrm{mol}$. Finally, for Covid-19 main protease (6M03), Vtocdea and VXn are amongst the highest molecules in terms of binding affinity with the specific protein. Vtocdea interacts through hydrogen bonds with SER255 and PRO322 (2 H bonds) whereas, VXn interacts through hydrogen bonds with the amino acids GLN110 and THR111. All the detailed information about the energy amounts of the ligand molecules through the different proteins and the hydrophobic interactions of the amino acids with these molecules can be found in Table 3 .

Table 3. $\Delta \mathrm{G}_{\text {bind }}$ energies and amino acid residues of the molecules interacting with BSA, 6YI3, 6M71 and 6M03. 


\begin{tabular}{|c|c|c|c|c|c|c|}
\hline $\begin{array}{l}\text { Complex } \\
\text { (Protein- } \\
\text { Ligand) }\end{array}$ & $\begin{array}{c}\Delta \mathrm{G}_{\text {bind }} \\
(\mathrm{Kcal} / \mathrm{mol})\end{array}$ & $\begin{array}{c}\text { Van } \\
\text { der } \\
\text { Waals } \\
\end{array}$ & $\begin{array}{l}\text { Hydrogen } \\
\text { Bond }\end{array}$ & $\begin{array}{c}\text { Electrostatic } \\
\text { Forces }\end{array}$ & $\begin{array}{l}\text { Amino acids that } \\
\text { interact through } \\
\text { hydrogen bonds }\end{array}$ & $\begin{array}{c}\text { Amino acids that make } \\
\text { hydrophobic } \\
\text { interactions }\end{array}$ \\
\hline $\begin{array}{l}\text { Vbicah- } \\
\text { BSA }\end{array}$ & -85.81 & -71.51 & -14.3 & 0 & LEU304, HIS304 & $\begin{array}{c}\text { LEU301, PRO302, } \\
\text { PRO303(M*), PRO303(S*), } \\
\text { LEU304, TYR333, } \\
\text { ARG336, HIS337, PHE373 }\end{array}$ \\
\hline $\begin{array}{l}\text { Vbicah- } \\
6 \text { YI3 }\end{array}$ & -108.88 & -79.63 & -29.25 & 0 & $\begin{array}{l}\text { ASP23, LYS25, ASN86, } \\
\text { GLY89, TRP92 }\end{array}$ & $\begin{array}{c}\text { ASP23, ASN86(M), } \\
\text { ASN86(S), ASP88, ILE90, } \\
\text { TRP92 }\end{array}$ \\
\hline $\begin{array}{l}\text { Vbicah- } \\
6 \mathrm{M71}\end{array}$ & -102.66 & -65.5 & -37.16 & 0 & $\begin{array}{l}\text { TYR129, HIS133, } \\
\text { SER709, THR710, } \\
\text { ASP711, LYS714, } \\
\text { ASN781 }\end{array}$ & $\begin{array}{c}\text { TYR32, TYR129, SER709, } \\
\text { LYS780, ASN781 }\end{array}$ \\
\hline $\begin{array}{l}\text { Vbicah- } \\
\text { 6M03 }\end{array}$ & -106.62 & -47.26 & -59.37 & 0 & $\begin{array}{l}\text { HIS41, SER46, LEU141, } \\
\text { ASN142, GLY143, } \\
\text { SER144(M), SER144(S), } \\
\text { CYS145(M), CYS145(S), } \\
\text { HIS163, GLU166 }\end{array}$ & $\begin{array}{c}\text { HIS41, MET49, } \\
\text { ASN142(M), ASN142(S), } \\
\text { HIS163, GLU166 }\end{array}$ \\
\hline $\begin{array}{l}\text { Vbdea- } \\
\text { BSA }\end{array}$ & -85.66 & -57.44 & -28.22 & 0 & $\begin{array}{l}\text { HIS145, SER192, } \\
\text { SER428, ARG458 }\end{array}$ & $\begin{array}{l}\text { LEU189, SER192, } \\
\text { ARG196 }\end{array}$ \\
\hline $\begin{array}{l}\text { Vbdea- } \\
6 \text { YI3 }\end{array}$ & -86.78 & -66.63 & -20.15 & 0 & $\begin{array}{l}\text { ASP23, LYS25, GLY89, } \\
\text { ILE90 }\end{array}$ & $\begin{array}{l}\text { ASN86(M), ASN86(S), } \\
\text { ASP88, ILE91, TRP92 }\end{array}$ \\
\hline $\begin{array}{l}\text { Vbdea- } \\
\text { 6M71 }\end{array}$ & -86.47 & -65.28 & -21.19 & 0 & $\begin{array}{c}\text { LYS47, ASN138, ASP140, } \\
\text { THR141(M), THR141(S), } \\
\text { LEU142 }\end{array}$ & $\begin{array}{l}\text { TYR32, LYS47, ALA130, } \\
\text { ASP140, THR141 }\end{array}$ \\
\hline $\begin{array}{l}\text { Vbdea- } \\
6 \mathrm{M} 03\end{array}$ & -87.35 & -71.16 & -16.18 & 0 & $\begin{array}{c}\text { GLY143, SER144(M), } \\
\text { SER144(S), CYS145, } \\
\text { HIS163 }\end{array}$ & $\begin{array}{l}\text { HIS41, SER46, MET49, } \\
\text { LEU141, ASN142, } \\
\text { MET165, GLN189 } \\
\end{array}$ \\
\hline $\begin{array}{l}\text { Vtocdea- } \\
\text { BSA }\end{array}$ & -85.52 & -81.6 & -3.5 & -0.42 & ASN161 & $\begin{array}{l}\text { ASP129, GLU130(M), } \\
\text { GLU130(S), LYS131(M), } \\
\text { LYS131(S), TRP134, } \\
\text { ASN158, ASN161 }\end{array}$ \\
\hline $\begin{array}{l}\text { Vtocdea- } \\
6 \text { YI3 }\end{array}$ & -78.58 & -78.58 & 0 & 0 & ------ & $\begin{array}{c}\text { THR14, ALA116, ILE117, } \\
\text { VAL118, GLN120, } \\
\text { GLU134, GLY135 }\end{array}$ \\
\hline $\begin{array}{l}\text { Vtocdea- } \\
6 \mathrm{M} 71\end{array}$ & -98.91 & -93.41 & -5.5 & 0 & SER255, PRO322 & $\begin{array}{c}\text { TYR265, LYS267, } \\
\text { TRP268(M), TRP268(S), } \\
\text { ASP269(M), ASP269(S), } \\
\text { LEU270, PRO322(M), } \\
\text { PRO322(S) }\end{array}$ \\
\hline $\begin{array}{l}\text { Vtocdea- } \\
6 \mathrm{M} 03\end{array}$ & -86.01 & -76.32 & -9.98 & 0.29 & GLN110, ASN203 & $\begin{array}{l}\text { GLY109, GLN110, } \\
\text { VAL202, ASN203, } \\
\text { GLU240, PRO241, } \\
\text { HIS246, ILE249 }\end{array}$ \\
\hline $\begin{array}{l}\text { Vtocdpa- } \\
\text { BSA }\end{array}$ & -99.14 & -94.43 & -6.33 & 1.62 & ARG144 & $\begin{array}{c}\text { ASP111, LEU112, } \\
\text { PRO113, LYS114(M), } \\
\text { LYS114(S), LEU115(M), } \\
\text { LEU115(S), ARG144, } \\
\text { ARG185, GLU424, ILE522 }\end{array}$ \\
\hline $\begin{array}{l}\text { Vtocdpa- } \\
6 \text { YI3 }\end{array}$ & -96.79 & -93.29 & -3.5 & 0 & LEU149 & $\begin{array}{c}\text { HIS19, LEU121, } \\
\text { THR126(M), THR126(S), } \\
\text { LEU127(M), LEU127(S), }\end{array}$ \\
\hline
\end{tabular}




\begin{tabular}{|c|c|c|c|c|c|c|}
\hline & & & & & & $\begin{array}{c}\text { PRO128, LYS129, } \\
\text { GLY130, PHE131, TYR132 }\end{array}$ \\
\hline $\begin{array}{l}\text { Vtocdpa- } \\
6 \mathrm{M71}\end{array}$ & -97.06 & -89.12 & -5 & -2.94 & ASP761 & $\begin{array}{l}\text { HIS439, SER549, } \\
\text { ARG555, TRP617, } \\
\text { GLU811, CYS813, } \\
\text { SER814, ARG836 }\end{array}$ \\
\hline $\begin{array}{l}\text { Vtocdpa- } \\
\text { 6M03 }\end{array}$ & -87.24 & -84.32 & -2.74 & -0.18 & HIS246 & $\begin{array}{l}\text { GLN107, PRO108, } \\
\text { GLY109, VAL202, } \\
\text { GLU240, HIS246 }\end{array}$ \\
\hline $\begin{array}{l}\text { VXn- } \\
\text { BSA }\end{array}$ & -108.72 & -93.23 & -15.5 & 0 & $\begin{array}{l}\text { ASP108, PRO146, } \\
\text { TYR147, ILE455 }\end{array}$ & $\begin{array}{c}\text { HIS145(M), HIS145(S), } \\
\text { LEU189(M), LEU189(S), } \\
\text { SER192, ALA193(M), } \\
\text { ALA193(S), ARG196, } \\
\text { ARG458 }\end{array}$ \\
\hline $\begin{array}{l}\text { VXn- } \\
6 Y I 3\end{array}$ & -105.23 & -74.36 & -30.87 & 0 & $\begin{array}{c}\text { PHE26, ARG28, TYR83, } \\
\text { TRP92, THR95 }\end{array}$ & $\begin{array}{c}\text { ARG28(M), ARG28(S), } \\
\text { TYR83, TRP92, VAL93(M), } \\
\text { VAL93(S) }\end{array}$ \\
\hline $\begin{array}{l}\text { VXn- } \\
6 \mathrm{M} 71\end{array}$ & -93.64 & -80.61 & -13.03 & 0 & ARG29, THR252 & $\begin{array}{c}\text { THR246, LEU247, } \\
\text { ARG249, THR319, } \\
\text { LEU460, PRO461 }\end{array}$ \\
\hline $\begin{array}{l}\text { VXn- } \\
6 \mathrm{M} 03\end{array}$ & -91.83 & -79.41 & -12.42 & 0 & GLN110, THR111 & $\begin{array}{c}\text { GLY109, GLN110(M), } \\
\text { GLN110(S), THR292, } \\
\text { PHE294 }\end{array}$ \\
\hline $\mathrm{Xn}$-BSA & -103.32 & -94.04 & -9.28 & 0 & ARG458 & $\begin{array}{c}\text { ASP108, HIS145, } \\
\text { LEU189(M), LEU189(S), } \\
\text { SER192(M), SER192(S), } \\
\text { ALA193, ARG196, } \\
\text { ARG458 }\end{array}$ \\
\hline Xn-6YI3 & -87.4 & -70.41 & -17 & 0 & $\begin{array}{l}\text { PRO122, GLN123(M), } \\
\text { GLN123(S), GLY124 }\end{array}$ & $\begin{array}{c}\text { GLN120, LEU121, } \\
\text { PRO122, GLN123(M), } \\
\text { GLN123(S), GLY124, } \\
\text { THR126 }\end{array}$ \\
\hline $\begin{array}{c}\mathrm{Xn}- \\
6 \mathrm{M} 71\end{array}$ & -96.03 & -74.54 & -21.49 & 0 & $\begin{array}{c}\text { LYS621(M), LYS621(S), } \\
\text { ARG624 }\end{array}$ & $\begin{array}{c}\text { ARG553, ASP618, } \\
\text { TYR619, PRO620, LYS621, } \\
\text { ASP623, ARG624, ASP760 }\end{array}$ \\
\hline $\begin{array}{l}\mathrm{Xn}- \\
6 \mathrm{M} 03\end{array}$ & -80.46 & -62.77 & -17.7 & 0 & $\begin{array}{c}\text { ASP33, ASP34, } \\
\text { SER81(M), SER81(S), } \\
\text { LYS88 }\end{array}$ & $\begin{array}{l}\text { ASP33, VAL35, LYS88, } \\
\text { LEU89, LYS90(M), } \\
\text { LYS90(S), TYR101 }\end{array}$ \\
\hline
\end{tabular}

${ }^{*} \mathrm{M}$ stands for main chain of the protein whereas $\mathrm{S}$ stands for the side chain of the protein

The presence of the electrostatic forces on those interactions was limited. Electrostatic interactions can only be seen on the interaction between Vtocdea with BSA $(-0.42 \mathrm{Kcal} / \mathrm{mol})$, Vtocdea with $6 \mathrm{M} 03(0.29$ $\mathrm{Kcal} / \mathrm{mol})$, Vtocdpa with BSA $(1.62 \mathrm{Kcal} / \mathrm{mol})$, Vtocdpa with $6 \mathrm{M} 71(-2.94 \mathrm{Kcal} / \mathrm{mol})$ and Vtocdpa with $6 \mathrm{M} 03(-0.18 \mathrm{Kcal} / \mathrm{mol})$. The electrostatic interactions of Vtocdea and Vtocdpa are in correlation with literature [17], indicating that these molecules are having anticancer activity through the disruptions of electron transfer cycle in mitochondria. Having in mind the theoretical studies we suggest that molecules such as Vtocdea and VXn are good candidates to tested in vitro and in vivo, against the Covid-19 disease.

\section{Conclusions}


In this study we performed several theoretical studies on vanadium complexes with biological activity from the literature. Based on that, we designed a new one the VXn molecule that showed similar activity with Vtocdea. We used computational chemistry methods to take valuable information of the molecules and performed molecular docking studies on Covid-19 related structures. Knowing from literature that Vtocdea exhibits the highest biological activity having at the same time the least toxicity in healthy cells, we conclude that these techniques should be used by the scientific community to save time and money on the fight against Covid-19 and take these valuable information in order to discover novel drug therapies with high effectiveness and the least toxicity.

\section{Declarations}

\section{Disclosure statement}

No potential conflict of interest was reported by the authors.

\section{ORCID}

https://orcid.org/0000-0002-8356-0868

\section{References}

[1] Abd El-Aziz, T. M.; Stockand, J. D. Recent Progress and Challenges in Drug Development against COVID-19 Coronavirus (SARS-CoV-2) - an Update on the Status. Infect. Genet. Evol., 2020, 83 (April), 104327. https://doi.org/10.1016/j.meegid.2020.104327.

[2] Ibrahim, I. M.; Abdelmalek, D. H.; Elshahat, M. E.; Elfiky, A. A. COVID-19 Spike-Host Cell Receptor GRP78 Binding Site Prediction. J. Infect., 2020, 80 (5), 554-562.

https://doi.org/10.1016/j.jinf.2020.02.026.

[3] Yan, R.; Zhang, Y.; Li, Y.; Xia, L.; Guo, Y.; Zhou, Q. Structural Basis for the Recognition of SARS-CoV-2 by Full-Length Human ACE2. Science (80-. )., 2020, 367 (6485), 1444-1448.

https://doi.org/10.1126/science.abb2762.

[4] Lai, C. C.; Shih, T. P.; Ko, W. C.; Tang, H. J.; Hsueh, P. R. Severe Acute Respiratory Syndrome Coronavirus 2 (SARS-CoV-2) and Coronavirus Disease-2019 (COVID-19): The Epidemic and the Challenges. Int. J. Antimicrob. Agents, 2020, 55 (3), 105924.

https://doi.org/10.1016/j.ijantimicag.2020.105924.

[5] Liu, X.; Zhang, B.; Jin, Z.; Yang, H.; Rao, Z. The Crystal Structure of COVID-19 Main Protease in Complex with an Inhibitor N3. PDB release, 2020, 119 (February), 17-20. https://doi.org/10.2210/PDB6LU7/PDB. 
[6] Shi, Y.; Zhang, X.; Mu, K.; Peng, C.; Zhu, Z.; Wang, X.; Yang, Y.; Xu, Z.; Zhu, W. D3Targets-2019-NCoV: A Webserver for Predicting Drug Targets and for Multi-Target and Multi-Site Based Virtual Screening against COVID-19. Acta Pharm. Sin. B, 2020, No. xxx. https://doi.org/10.1016/j.apsb.2020.04.006.

[7] Dinesh, D. C.; Chalupska, D.; Silhan, J.; Veverka, V.; Boura, E. Structural Basis of RNA Recognition by the SARS-CoV-2 Nucleocapsid Phosphoprotein. bioRxiv, 2020, 2020.04.02.022194. https://doi.org/10.1101/2020.04.02.022194.

[8] Lung, J.; Lin, Y. S.; Yang, Y. H.; Chou, Y. L.; Shu, L. H.; Cheng, Y. C.; Liu, H. Te; Wu, C. Y. The Potential Chemical Structure of Anti-SARS-CoV-2 RNA-Dependent RNA Polymerase. J. Med. Virol., 2020, 92 (6), 693-697. https://doi.org/10.1002/jmv.25761.

[9] Ferreira, L. G.; Dos Santos, R. N.; Oliva, G.; Andricopulo, A. D. Molecular Docking and Structure-Based Drug Design Strategies; 2015; Vol. 20. https://doi.org/10.3390/molecules200713384.

[10] Luque, F. J. Frontiers in Computational Chemistry for Drug Discovery. Molecules, 2018, 23 (11). https://doi.org/10.3390/molecules23112872.

[11] Pirhadi, S.; Sunseri, J.; Koes, D. R. Open Source Molecular Modeling. J. Mol. Graph. Model., 2016, 69, 127-143. https://doi.org/10.1016/j.jmgm.2016.07.008.

[12] Miteva, M. A.; Violas, S.; Montes, M.; Gomez, D.; Tuffery, P.; Villoutreix, B. O. FAF-Drugs: Free ADME/Tox Filtering of Compound Collections. Nucleic Acids Res., 2006, 34 (WEB. SERV. ISS.), 738-744. https://doi.org/10.1093/nar/gkl065.

[13] De Clercq, E. Antiviral Metal Complexes. Met. Based. Drugs, 1997, 4 (3), 173-192. https://doi.org/10.1155/MBD.1997.173.

[14] Biju, S.; Parac-Vogt, T. N. Recent Advances in Lanthanide Based Nano-Architectures as Probes for Ultra High-Field Magnetic Resonance Imaging. Curr. Med. Chem., 2018, 27 (3), 352-361. https://doi.org/10.2174/0929867325666180201110244.

[15] Ghaffari, H.; Tavakoli, A.; Moradi, A.; Tabarraei, A.; Bokharaei-Salim, F.; Zahmatkeshan, M.; Farahmand, M.; Javanmard, D.; Kiani, S. J.; Esghaei, M.; et al. Inhibition of H1N1 Influenza Virus Infection by Zinc Oxide Nanoparticles: Another Emerging Application of Nanomedicine. J. Biomed. Sci., 2019, 26 (1), 1-10. https://doi.org/10.1186/s12929-019-0563-4.

[16] Langland, J.; Jacobs, B.; Wagner, C. E.; Ruiz, G.; Cahill, T. M. Antiviral Activity of Metal Chelates of Caffeic Acid and Similar Compounds towards Herpes Simplex, VSV-Ebola Pseudotyped and Vaccinia Viruses. Antiviral Res., 2018, 160, 143-150. https://doi.org/10.1016/j.antiviral.2018.10.021.

[17] Hadjiadamou, I.; Vlasiou, M.; Spanou, S.; Simos, Y.; Papanastasiou, G.; Kontargiris, E.; Dhima, I.; Ragos, V.; Karkabounas, S.; Drouza, C.; et al. Synthesis of Vitamin E and Aliphatic Lipid Vanadium(IV) and 
(V) Complexes, and Their Cytotoxic Properties. J. Inorg. Biochem., 2020, No. Iv, 111074. https://doi.org/10.1016/j.jinorgbio.2020.111074.

[18] Drouza, C.; Vlasiou, M.; Keramidas, A. D. Vanadium(IV/V)-p-Dioxolene Temperature Induced Electron Transfer Associated with Ligation/Deligation of Solvent Molecules. Dalton Trans., 2013, 42 (33), 1183111840. https://doi.org/10.1039/c3dt50619c.

[19] Drouza, C.; Vlasiou, M.; Keramidas, A. D. Synthesis, Characterization of Dinuclear Vanadium(III) Hydroquinonate- Iminodiacetate Complexes. Inorganica Chim. Acta, 2014, 420, 103-111. https://doi.org/10.1016/j.ica.2013.12.033.

[20] Wakui, N.; Yoshino, R.; Yasuo, N.; Ohue, M.; Sekijima, M. Exploring the Selectivity of Inhibitor Complexes with Bcl-2 and Bcl-XL: A Molecular Dynamics Simulation Approach. J. Mol. Graph. Model., 2018, 79, 166-174. https://doi.org/10.1016/j.jmgm.2017.11.011.

[21] Rocha, J. A.; Rego, N. C. S.; Carvalho, B. T. S.; Silva, F. I.; Sousa, J. A.; Ramos, R. M.; Passos, I. N. G.; De Moraes, J.; Leite, J. R. S. A.; Lima, F. C. A. Computational Quantum Chemistry, Molecular Docking, and ADMET Predictions of Imidazole Alkaloids of Pilocarpus Microphyllus with Schistosomicidal Properties. PLoS One, 2018, 13 (6), 1-23. https://doi.org/10.1371/journal.pone.0198476.

[22] Hayakawa, D.; Sawada, N.; Watanabe, Y.; Gouda, H. A Molecular Interaction Field Describing Nonconventional Intermolecular Interactions and Its Application to Protein-Ligand Interaction Prediction. J. Mol. Graph. Model., 2020, 96, 107515. https://doi.org/10.1016/j.jmgm.2019.107515

[23] Yin, Y.; Sun, Y.; Zhao, L.; Pan, J.; Feng, Y. Medicinal Chemistry Based Amides as Potent S6K1 Inhibitors †. 2020. https://doi.org/10.1039/c9md00537d.

[24] Ercan, S.; Şenses, Y. Design and Molecular Docking Studies of New Inhibitor Candidates for EBNA1 DNA Binding Site: A Computational Study. Mol. Simul., 2020, 46 (4), 332-339.

https://doi.org/10.1080/08927022.2019.1709638.

[25] Çakmak, E.; Özbakır Işın, D. A Theoretical Evaluation on Free Radical Scavenging Activity of 3Styrylchromone Derivatives: The DFT Study. J. Mol. Model., 2020, 26 (5).

https://doi.org/10.1007/s00894-020-04368-7.

[26] Tian, Y.; Chen, W.; Zhao, Z.; Xu, L.; Tong, B. Interaction and Selectivity of 14-Crown-4 Derivatives with $\mathrm{Li}+$, Na+, and Mg2+ Metal lons. J. Mol. Model., 2020, 26 (4). https://doi.org/10.1007/s00894-020-4325-8.

[27] Mendizabal, F.; Miranda-Rojas, S.; Castro-Latorre, P. Quantum Chemistry Simulation of the Electronic Properties in [Au(NH3)2] NO3 and [Au(NCH)2][AuCl4] Extended Unsupported Complexes. Mol. Simul., 2020, $O(0), 1-9$. https://doi.org/10.1080/08927022.2020.1735634.

[28] Praski, A.; Jaworska, M.; Lodowski, P. Structure and Electronic Spectra of Neutral and Protonated Forms of Anticonvulsant Drug Lamotrigine. J. Mol. Model., 2020, 26 (3). https://doi.org/10.1007/s00894- 
[29] Mohd Amin, S. N.; Md Idris, M. H.; Selvaraj, M.; Mohd Amin, S. N.; Jamari, H.; Kek, T. L.; Salleh, M. Z. Virtual Screening, ADME Study, and Molecular Dynamic Simulation of Chalcone and Flavone Derivatives as 5-Lipoxygenase (5-LO) Inhibitor. Mol. Simul., 2020, 46 (6), 487-496.

https://doi.org/10.1080/08927022.2020.1732961.

\section{Figures}
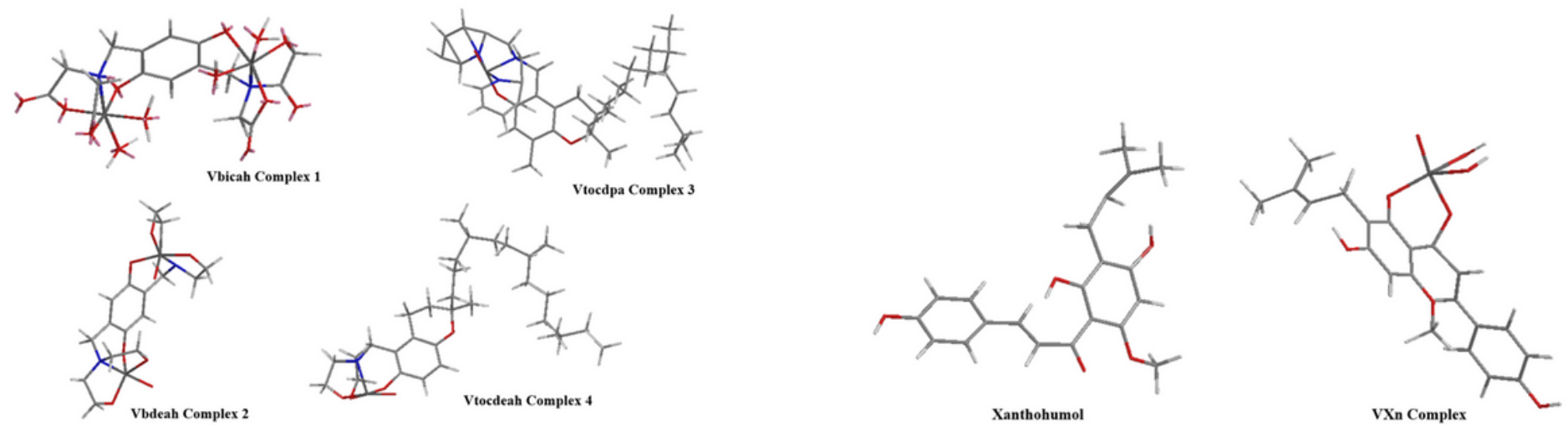

A

B

\section{Figure 1}

a. Optimized calculated structures of the Vanadium complexed molecules. b. Optimized calculated structures of xanthohumol and its design vanadium complexed structure.

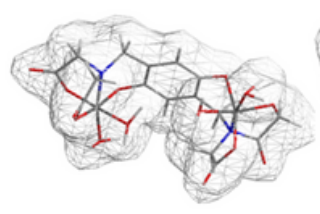

Vbicah Total Charge Density

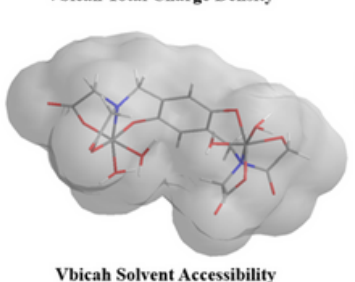

Vbicah Solvent Accessibility

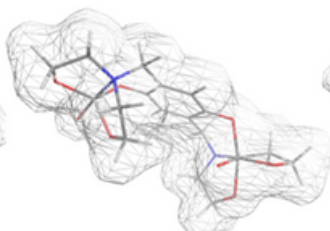

Vbdeah Total Charge Density

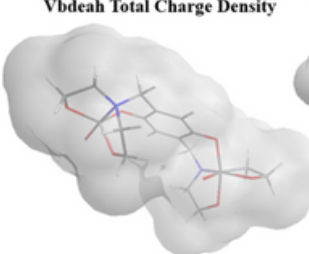

Vbdeah Solvent Accessibility

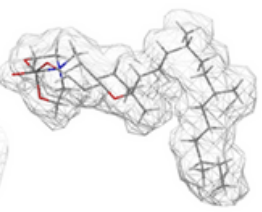

Vtocdeah Total Charge Density

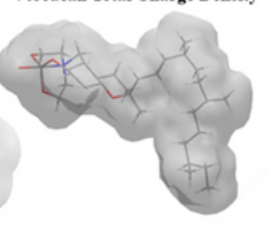

Vtocdeah Solvent Accessibility
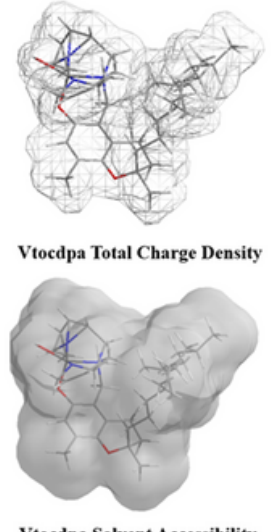

Vtocdpa Solvent Accessibility

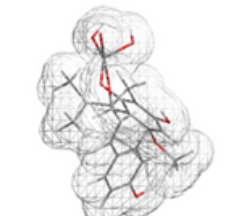

vXn Total Charge Density

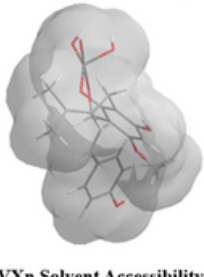

VXn Solvent Accessibility

B

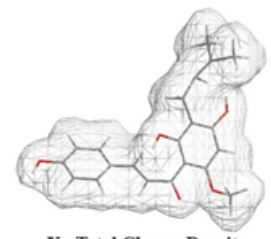

Xn Total Charge Density

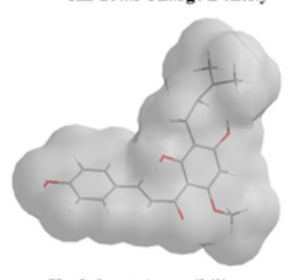

Xn Solvent Accessibility

A

\section{Figure 2}

a. Total charge densities and solvent accessibilities for Vbicah, Vbdeah and Vtocdea complex molecules.

b. Total charge densities and solvent accessibilities for Vtocdpa, VXn complex molecules and Xanthohumol molecule. 


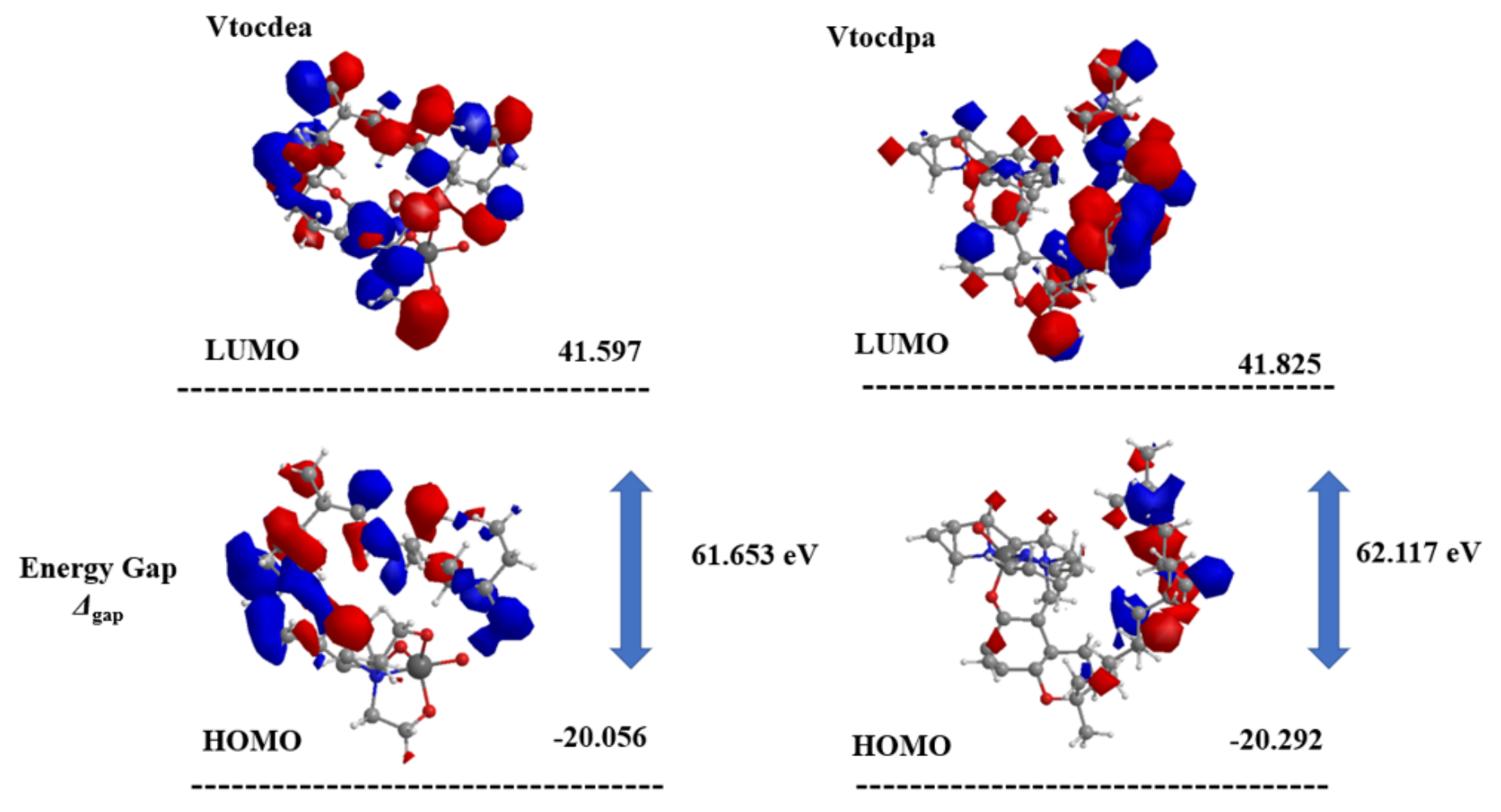

Figure 3

HOMO and LUMO molecular orbital of Vtocdea and Vtocdpa. 


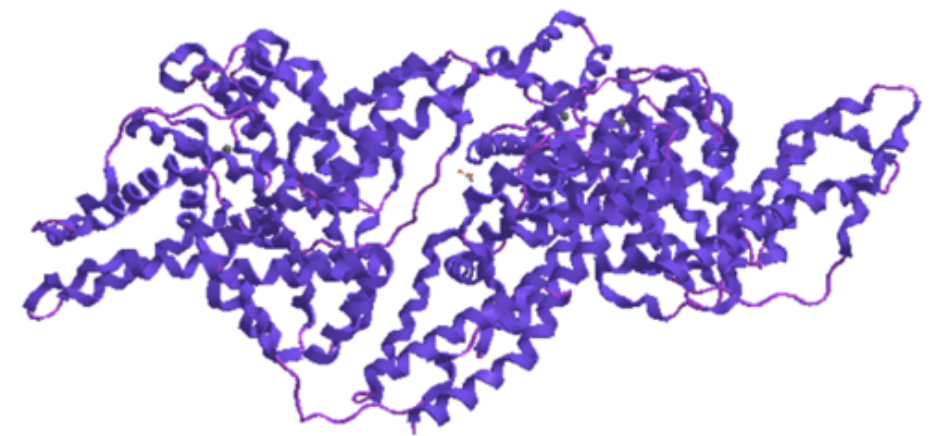

Bovine Serum Albumin BSA

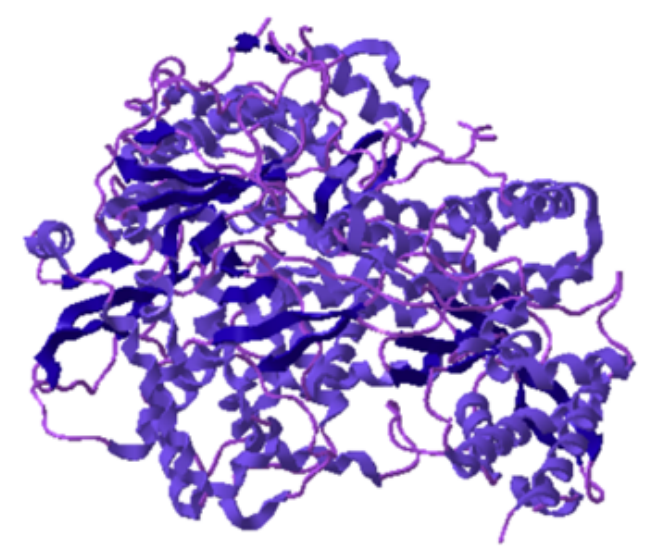

SARS-Cov-2 RNA-dependent RNA polymerase
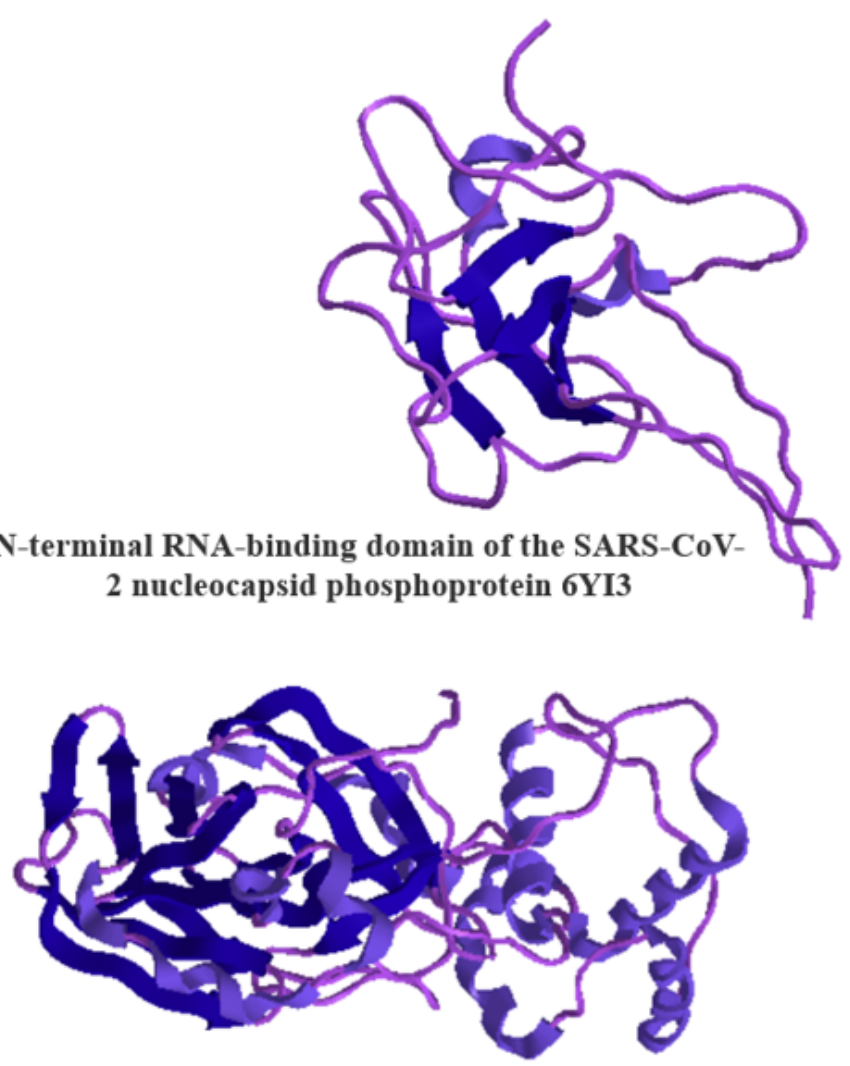

Crystal structure of COVID-19 main protease

\section{Figure 4}

The crystal structures of the proteins that studied theoretically. 


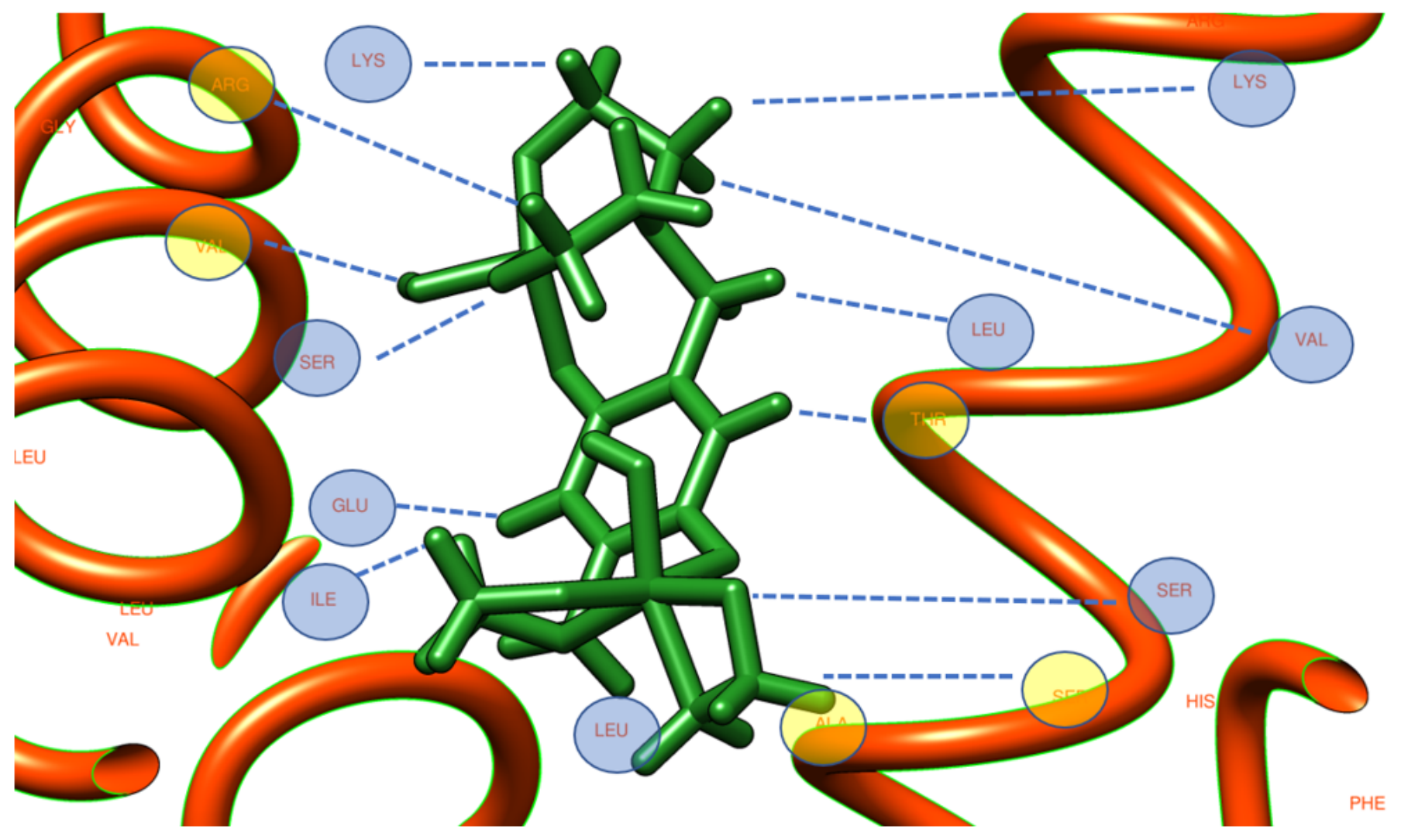

Figure 5

The amino acid binding residue of Vtocdea molecule with 6YI3. 

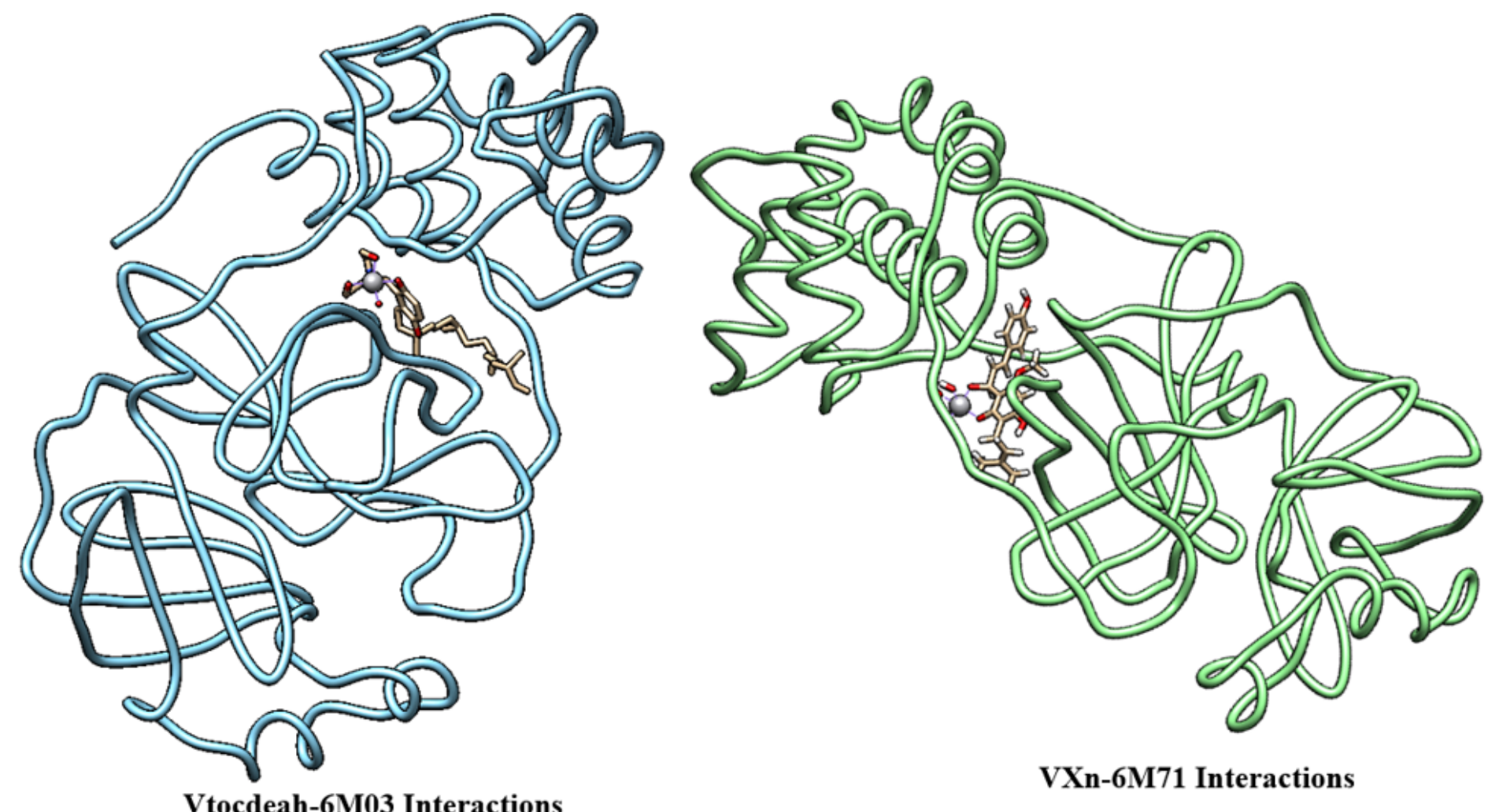

VXn-6M71 Interactions

Figure 6

Binding structures of Vtocdeah-6M03 and VXn-6M71 interactions. 


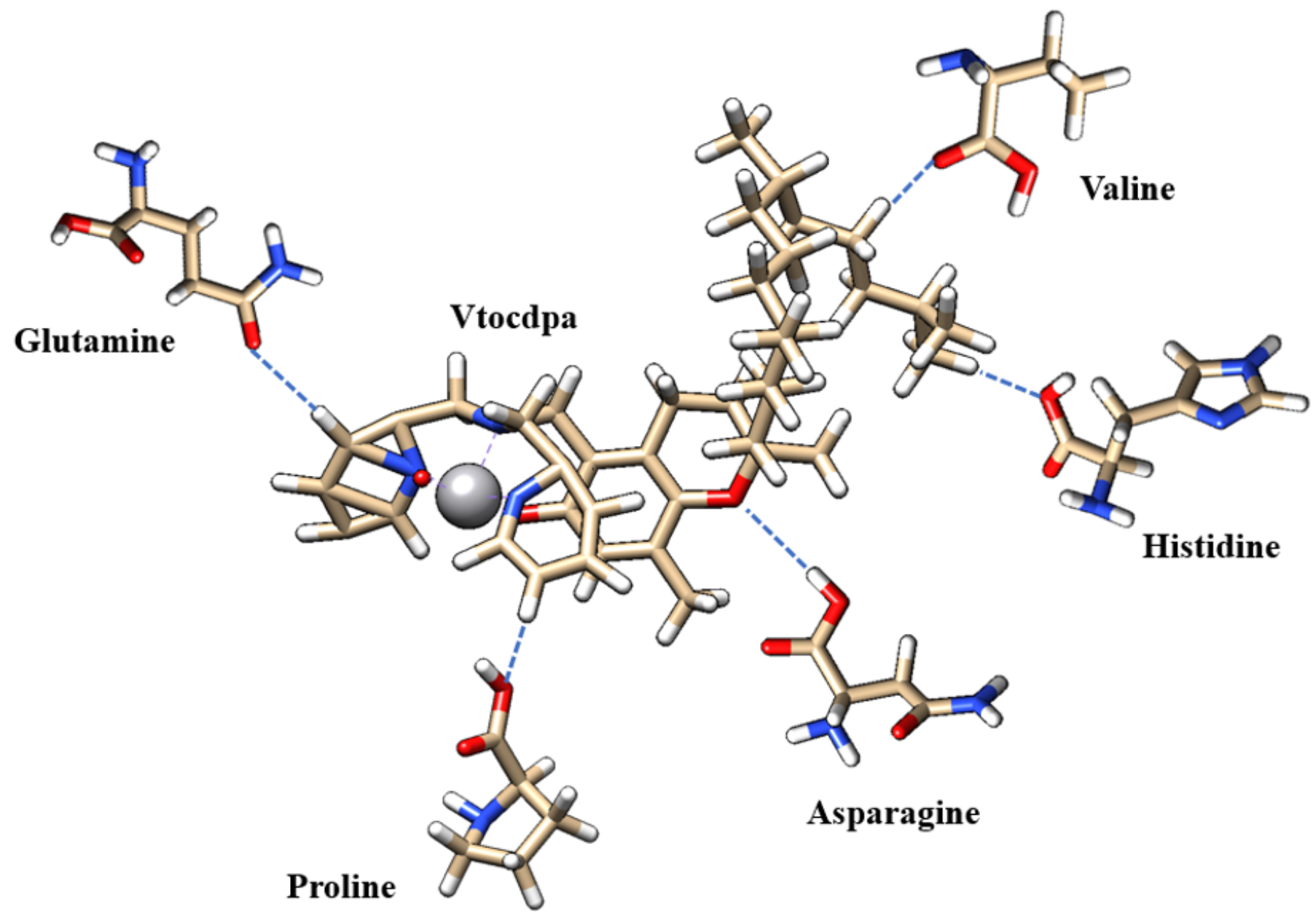

Figure 7

The interactions of Vtocdpa with 6M71 amino acid residues. 


\section{Residue}

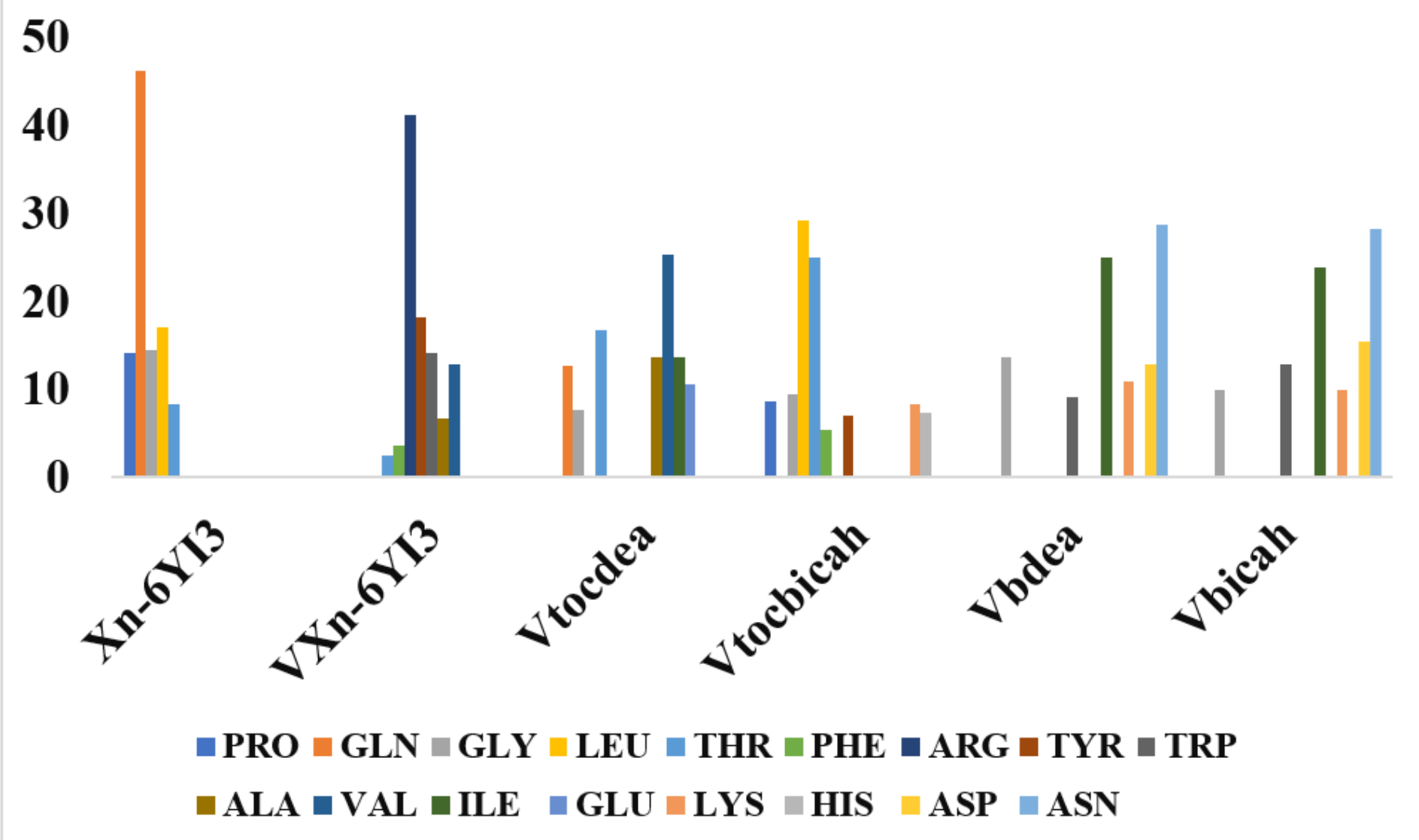

Figure 8

The percentage interaction energies of the responsible amino acids of $6 \mathrm{YI} 3$ on the different molecules studied in this work.

\section{Supplementary Files}

This is a list of supplementary files associated with this preprint. Click to download.

- Supplementary.pdf 